\title{
Under Rhodes' Eyes: The 'Old' and the 'New' International Law at Looking Distance
}

Keywords: Bibliography; New Approaches to International Law; Oxford ILA Conference.

Abstract: The Spring Conference of the British Branch of the International Law Association exemplified to the authors some of the ways in which the 'old' encounters the 'new' in contemporary international law. Followed by a selective Bibliography of newstream international legal writing, this Editorial tries to unravel the 'interested distance' maintained by the mainstream towards new trends in international legal scholarship.

Cecil Rhodes, then Prime Minister of Cape Colony, succeeded in the 1890 s in expanding British South African territory northwards, acquiring Mashonaland and Matabeleland, later named Rhodesia in his honor. Cecil Rhodes is remembered principally for furthering the British colonial cause and for his will, bequeathing some $£ 3,000,000$ for the establishment of the Rhodes Scholarships at Oxford University. About 100 years later, in a luxurious hall named in his honor, Rhodes' brooding eyes overlooked the plenary of a major European international law conference of Spring 1998 from a life-size painting. ${ }^{1}$ This editorial note is devoted to the Oxford Conference and, in particular, to what the authors experienced as its most interesting aspect, namely the encounter between international law's 'old' and 'new', its center and its periphery, its establishment and the barricades, i.e., the 'mainstream' and the 'newstream'.

We have seen arguments claiming that a new strcam of intcrnational lcgal scholarship has emerged, challenging on many fronts the prevailing conception of international law. ${ }^{2}$ Most of the newstream writing has revolved

1. Conference on The Role of Law in International Politics, 24-25 April 1928, Rhodes I Iousc, Oxford, England, organized by the British Branch of the International Law Association, in cooperation with the Center of International Studies and the Center of Socio-Legal Studies of Oxford University. The procecdings of the Conferenec will be published in the form of a book in Fall 1998 (Oxford Conference).

2. H. Charlesworth, Cries and Whispers: Responses to Feminist Scholarship in International Law, 65 Nordic Journal of International Law 557 (1996); O. Korhonen, New Internutiunul Luw. Silence, Defense, or Deliverance, 7 EJIL 1 (1996); and T. Skouteris, Fin de NAIL: New Approaches to International Law and Its Impact on Contemporary International Legal Scholar ship, 10 LJIL 415-420 (1997). For some icpiesentative accounts of sucli writing see, e.g., D.Z.

11 Leiden Joumal of Intemational Law 429-440 (1998)

(C) 1998 Kluwer Law Intemational 
around the rubric of the New Approaches to International Law (NAIL) and has presented a voluminous bibliography and extensive scholarly presence. ${ }^{3}$ Some worry, however, that there is a spectacular absence of an engaged response to the newstream critique by the mainstream and a lack of dialogue. At the same time, we have seen that the newstream has not been totally ignored: its works are cited and some 'newstreamers' are invited to conferences and are generally applauded. The question is why many feel that there is a lack of meaningful debate. The 'old' seems to be standing at a looking distance, gazing over the 'new', curious but un-involved. The situation of this 'interested distance', as it presented itself to the authors at the Oxford Conference, is what the following pages will attempt to unravel.

There are three levels in which the mainstream seemed to recognize the meaning and significance of the arguments and positions of the newstream.

First, there was recognition in what we will call the four corners of the argument. By four corners we refer to the 'scheme', the mode of delivery, the structure of the argument and the formula of what constitutes acceptable scholarly academic writing in international law in the nineties. Recognizing in the four corners of the argument concerns the extent to which the epistemology, the method, the aesthetics of the 'new' is experienced 'as own' by the 'old'. Therefore, to the extent that newstream argument seems to share a modernist epistemology (logical propositions, providing reasons to ground those propositions, rationally constructed models and arguments), it registers to a mainstream audience as intuitively acceptable in its formulation. To the extent that it is formalist in its method (rigorous study of material, thorough investigation of the classics of the discipline, respect towards the philosophical and historical tradition of international law), it feels intuitively respectful and legitimate in its constitution. To the extent that its aesthetics do not deviate from the standard stocks (it maintains essentially 'legal' jargon, it is eloquent, and mildly exciting as a text), it sounds attractive and non-alienating. In case of such a recognition, the newstreamer is branded as a 'guest', a newcomer, who is nevertheless admitted to the professional community of international jurists on account of his/her willingness to share some of the existing assumptions and semantic structures; but also on account of his/her interim submission to the mainstream authority to define those assumptions and structures.

In recognizing in the four corners, the mode of delivery of the newstream argument is acknowledged, hut not necessarily its substantive claims or their

Cass, Navigating the Newstrcam: Recent Critical Scholarship in Intomational Law, 65 Nordic Journal of International Law 341-383 (1996); D. Kennedy, A New Stream of International Law Scholarship, 7 Wisconsin International Law Journal 1-49 (1988-1989); and A. Carty, Critical Intemational Law: Recent Trends in the Theory of International Law, 2 EJIL 66-96 (1991).

3. For a selective bibliography of such writing, see A Selective Bibliography of Newsiream Writing, infra, at 434 et seq. 
consequences for the profession and the discipline. Actually, such a recognition is usually accompanied by deep scepticism over the substantive parts of the argument. To exemplify the point: during the Oxford Conference several speakers quoted isolated statements from the writings of Martti Koskenniemi, perhaps the leading proponent of European newstream writing. Although those quotations appealed to the speakers and the audience for their rationality, eloquence, and insight (they offered such a challenging entry point to the discussion!), Koskenniemi's overall project and argument was hardly debated or criticized. Koskenniemi was celebrated as a particularly perceptive and respectful newcomer whose overall project, however, goes well beyond the four corners of the nineties.

Second, there was by some a recognition of the cultural value of the critique represented by the newstream argument. The recognition of the cultural value of critique may appear under at least two names. First, under the name of 'progressivism' and the necessity for 'constructive' critique. The ncwstrcam, as the story goes, has the 'right' to criticize. 'Constructive' academic critique is the conditio sine qua non for the progress and improvement of the discipline. 'Constructive' critique is not only a permissible and legitimate academic task, but also a leading value and a habitual professional responsibility for the international jurist. Its footing in international legal culture is undisputed, especially on account of the European and Anglo-American persistence in an open-ended and liberal professional community. Such a critique is perceived to be especially necessary at times of great social change and the views from the margins could then have a fruitful impact on the discipline. The constructive critique, even when it appears unsettling, must be formally allowed to enter the professional discourse, and any transformative potential it may have, will then be evaluated fairly in the marketplace of values and eventually utilized - or not - by the professional community. There is, however, no obligation to accept or to respond to every such constructive critique. The absence of engaged response should not be interpreted as prejudice or indifference on the part of the professional community, but rather as a failure of the critique to convince. In this case the critique is taken to be simply misdirected, off-mark. The newstreamer is no longer an outsider, but an unsuccessful insider, perhaps an apprentice, or simply one incapable of formulating a relevant critique. Actually, the mainstream may become interested only once the constructivist credentials of the critique arc exhibitcd. To take another example at the Oxford Conference: an American colleague presented a newstream critique of contemporary human rights literature which received a great endorsement only once his constructivist commitment (to a 're-construction' of human rights debate) came to couple his critique during question time. Casting away any suspicion of nihilism and declaring a reconstructive project re-positioned him within the four comers and legitimized the critique. 
Under another name, there may be recognition of the social value of the critique as such. Provided it somehow remains within the four corncrs, and irrespective of its transformative potential, mainstream attention may be earned simply on account of the genius and novelty of the argument. In this latter case, the newstreamer is at best the genius, but other times the cranky scientist or the court's jester. The well-known speaker at Oxford who began by announcing the utopian character of his argument for the majority of the audience, captured the audience's full attention and sympathy but received no meaningful questions or responses.

There is recognition, finally, in what we will describe as $\alpha 1 \sigma \theta \eta \sigma 1 \zeta$ (aesthessis). Some mainstreamers do recognize in the newstream project an $\alpha \imath \sigma \theta \eta \sigma i c$, a sense, a meaning, a realizing aesthetics and epistemology of its

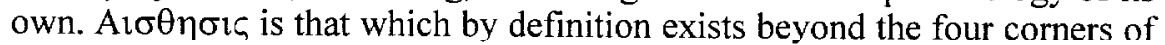
the argument. It is the ethical element which always escapes the technical, rational, modernist definitions of international law. It is the non-legal that is

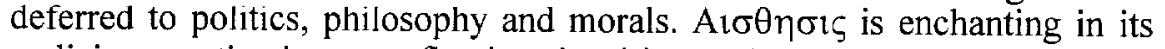
realizing, captivating, overflowing, inspiring and the audience experiences this enchantment. Being, however, instigaled by an external source (the newstream argument), $\alpha 1 \sigma \theta \eta \sigma 1 \zeta$ remains distant, alien, non-appropriated, when in private. It cannot be self-instigated unless founded in one's self. In this case the newstreamer becomes the artist, the poet, the philosopher, the

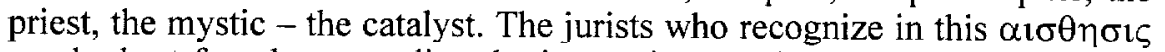
can be best found surrounding the interesting speaker at the break, longing for that additional word or explanation that will re-instigate the recognition.

In the newstream, the mainstream writing is widely discussed partly because there is no clear line between the two and partly because there is often a critical cmphasis. The ways of engagement differ greally. Annexed is a bibliography of representative writing in the newstream. The newstream writing, apart from the mentioned critical emphasis deals mostly with the widest questions of international law; it addresses the structural and fundamental questions at the basis of international legal work. For this reason, it is interested in all aspects of the mainstream research and also interesting and relevant to it. The basic idea is that if some problems seem to persist in the corpus of law and in the everyday of the international jurist despite the relentless efforts of generations of competent lawyers, then perhaps it is time to propose something 'completcly ncw' (thus the name). To find this 'new', without ending up like Icarus, demands detailed research into the traditions of international law, into the history of international legal thought, into the classics of international legal theory and the wider context of international law. As a consequence, many of the newstream works deal with the 'forgotten' topics of mainstream investigating into the gaps and shades between and beyond the most popular questions. This is neither an attempt at self- 
marginalisation, excess academicism, nor irrelevant theorising, but a proposal to shed light on the persistent/popular problcms from other sides.

For these reasons, it seems that the new and mainstream have all the basis to interact in the ways depicted above. As Hilary Charlesworth challenges, however, the newer writing is only rarely, if ever, a part of the professional know-how of the average scholar of international law. ${ }^{4}$ At the Oxford conference a clear change seemed to be on its way. It is probably impossible to decipher the key to the multi-faceted collection of newstream and then 'engage it'. It is hardly necessary. Instead we propose the reading of some representative writing included in the bibliography below and the reconnaissance of the insights that are common - but often forgotten - with one's own.

Thomas Skouteris \& Outi Korhonen

\title{
A Selective Bibliography of Newstream Writing
}

\author{
Compiled by Outi Korhonen \& Thomas Skouteris*
}

\section{Books}

Allott. P., Eunomia: New Order for a New World (1990)

Bartelson, J., A Genealogy of Sovereignty (1995).

Carty, A., The Decay of International Law: A Reappraisal of the Limits of Legal Imagination in International Affairs (1986).

Chimni, B.S., International Law and World Order: A Critique of Contemporary Approaches (1993)

Cook, R.J. (Ed.), Human Rights of Women: National and International Perspectives (1994)

Cossman, B., Law and International Development (1993).

4. Seo H. Charlesworth, Crics and Whispers: Responses to Feminist Schulurship in Internationul Law, 65 Nordic Journal of International Law 557 (1996).

* A larger version of the Bibliography was originally compiled with the inspiration and supervision of David Kennedy for the purposes of a scrics of conferences on the same topic. Fur all callier version of this bibliography, see D. Kennedy \& C. Tennant, New Approaches to International Law: A Bibliography, 35 Harvard International Law Journal 417 (1994). The present updated Selective Bibliography was researched and compiled in a larger version by Outi Külunen, alıd was pepared for publication with the collaboration of Thomas Skouteris.

The authors would like to express their gratitude to all who contributed to the Bibliography by sending information and correcting mistakes. We also apologizc for the necessary omissiuns which were based on the selection criteria of emphasis on international law, recent date of publication, and availability. 
Engle, K., \& Danielsen, D. (Eds.), After Identity: A Reader in Law and Culture (1995).

Fscarameia, P., Formation of Concepts in International Law: Subsumption under SelfDetermination in the Case of East Timor (1993).

Heiskanen, V.A., International Legal Topics (1992).

Kennedy, D., International Legal Structures (1987).

Klabbers, J., The Concept of Treaty in International Law (1996).

Koskenniemi, M., From Apology to Utopia: The Structure of International Legal Argument (1989).

Koskenniemi, M. (Ed.), International Law (1991).

Sassen, S., The Global City (1991).

\section{ARTICLES}

Abu-Udeh, L., Post-Colonial Heminism and the Vell: Considering the Differences, 26 New England Law Review 1527 (1992).

Addis, A., Individualism. Communitarianism. and the Rights of Ethnic Minorities, 67 Notre Dame Law Review 615 (1992).

Allott, P., State Responsibility and the Unmaking of International Law, 29 Harvard Internalional Law Jounal 1 (1988).

Allott, P., New International Law: The First Lecture of the Academic Year 20 [sic], in C. Warbrick et al. (Eds.), Theory and International Law: An Introduction 105 (1991).

Allott, P., Language, Method and the Nature of International Law, in M. Koskenniemi (Ed.), International Law 63 (1992).

Allott, P., Mare Nostrum: A New International Law of the Sea, 86 American Iournal of International Law 764 (1992).

Allott, P., Reconstituting Humanity - New International Law, 2 European Journal of International Law 219 (1992).

Allott, P., Self-determination - Absolute Right or Social Poetry?, in C. Tomuschat (Ed.), Modern Law of Self-Determination 177 (1993).

Allott, P., The International Court and the Voice of Justice, in V. Lowe \& M. Fitzmaurice (Eds.), Fifty Years of the International Court of Justice 17 (1996).

Anaya, S.J., The Capacity of International Law to Advance Ethnic or Nationality Rights Claims, 13 Human Rights Quarterly 403 (1991).

Anaya, S.J., A Contemporary Definition of the International Norm of Self-Determination, 2 Transnational Law \& Contemporary Problems 131 (1993).

Anghie, A., Human Rights and Cultural Identity: New Hope for Ethnic Peace?, 33 Harvard International Law Journal 341 (1992).

Anghie, A., "The Heart of My Home": Colonialism, Environmental Damage, and the Nauru Case, 34 Harvard International Law Journal 445 (1993).

Bartelson, J., The Trial of Judgement: A Note on Kant and the Paradoxes of Internationalism, 39 International Legal Studies Quarterly 255 (1995).

Bederman, D.J., Religion and the Sources of International Law in Antiquity, in M. Janis (Ed.), The Influence of Religion on the Development of International Law 3 (1991).

Bederman, D.J., Revivalist Canons and Treaty Interpretation, 41 University of California in Los Angeles Law Review 953 (1994).

Berman, N., A Perilous Ambivalence: Nationalist Desire, Legal Autonomy, and the Limits of the Interwar Framework, 33 Harvard International Law Journal 353 (1992). 
Berman, N., Sovereignty in Abeyance: Self-Determination and International Law, 7 Wisconsin Journal of International Law 51 (1988); and reproduced in M. Koskenniemi (Ed.), International Law 389 (1992).

Berman, N., "But the Alternative Is Despair": European Nationalism and the Modernist Renowal of Intornational Law, 106 Harvard Law Review 1792 (1993).

Berman, N., Modernism, Nationalism, and the Rhetoric of Reconstruction, 4 Yale Journal of Law and Humanities 351 (1992); and reproduced in 13 Current Legal Theory 3 (1995).

Berman, N., Beyond Colonialism and Nationalism? Ethiopia, Czechoslovakia and "Peaceful Change". 65 Nordic Journal of International Law 421 (1996).

Berman, N., Legalizing Jerusalem, or, of Law, Fantasy, and Faith, 45 Catholic University Law Review 823 (1996).

Boyle, J., Ideals and Things: International Legal Scholarship and the Prisonhousc of Language, 26 Harvard International Law Journal 327 (1985).

Byrnes, R., Women, Feminism and International Human Rights Law - Methodological Myopia, Fundamental Flaws or Meaningful Marginalisation? Some Current issues, 12 Australian Yearbook of International Law 205 (1992).

Carroll, A I. \& Rajagonal, B., The Case for the Independent Statehood of Somaliland, 8 American University Journal of International Law and Policy 653 (1992-1993).

Carty, A., Critical Theory and General Customary Law, 12 Marine Policy 211 (1988).

Carty, A., Critical Internationul Law. Recent Trends in the Theory of International Law, 2 European Journal of International Law 66 (1991).

Carty, A., Liberalism's Dangerous Supplements: Medieval Ghosts of International Law, 13 Michigan Journal of International Law 161 (1991).

Carty, A., Why Theory? The Implications for International Law Teaching, in C. Warbrick et al. (Eds.), Theory and International Law - An Introduction 73 (1991)

Carty, A., The Legal Discourse of Intervention and International Practice, in I. Forbes \& M. Hoffman (Eds.), International Relations, Political Theory and the Ethics of Intervention 32 (1993).

Carty, A., Some Aspects of the Present Discussion of the Place of Lawyers in Development, in A. Carty \& H.W. Singer (Eds.), Conflict and Change in the 1990s: Ethics, Law and Institutions 80 (1993).

Carty, A., Alfred Verdross and Othmar Spann. German Romantic Nationalism, National Socialism and International Law, 6 European Journal of International Law 78 (1995).

Carty, A., Interwar German Theories of International Law: The Psychoanalytical and Phenomenological Perspectives of Hans Kelsen and Carl Schmitt, 16 Cardozo Law Review 1235 (1995).

Cass, D.Z., Rethinking Self-Determination: A Critical Analysis of Current International low Theories, 18 Syracuse Journal of International Law and Commerce 21 (1992).

Cass, D.Z., Navigating the New Stream: Recent Critical Scholarship in International Law, 65 Nordic Journal of International Law 337 (1996).

Charlesworth, H., Chinkin, C. \& Wright, S., Feminist Approaches to International Law, 85 American Journal of International Law 613 (1991).

Charlesworth, H., The Public/Private Distinction and the Right to Development in International Law, 12 Australian Yearbook of International Law Annual 190 (1992).

Charlesworth, H., Alienating Oscar, in D. Dallmeyer (Ed.), Reconceiving Reality: Women and International Law 1 (1993)

Charlesworth, H. \& Chinkin, C., The Gender of Jus Cogens, 15 Human Rights Quarterly 63 (1993). 
Charlesworth, H., Transforming the United Men's Club: Feminist Futures for the United Nations, 4 Transnational Law and Contemporary Problems 421 (1995)

Charlesworth, H., Cries and Whispers: Responses to Feminist Scholarship in International Law, 65 Nordic Journal of International Law 557 (1996).

Chinmi, B.S., The Meuring of Words und the Role of UNHCR in Voluntary Repartation, 5 International Journal of Refugee Law 442 (1994).

Chimni, B.S., The Interaction of Victims: Deconstructing Safety Zones, in N. Al-Nauimi \& R. Meese (Eds.), International Legal Issues Under the United Nations Decade of International Law 73 (1995).

Cook, R.J., Human Rights and Development: Are Women Still Separate and Unequal?, reproduced in Proceedings of the 1986 Conference on International Law Development, Canadian Council on International Law 315 (1987).

Cook, R. J. \& Oosterveld, V.L., A Select Bibliography of Women's Human Rights, 44 American University Law Review 1429 (1995).

Coombe, R., The Cultural Life of Things: Anthropological Approaches to Law and Society in Conditions of Globalization, 10 American University Journal of International Law and Policy 791 (1995).

Cossman, B., Reform, Revolution, or Retrenchment? International Human Rights in the Post-Cold War Era, 32 Harvard International Law Journal 339 (1991).

Engle, K., International Human Rights and Feminism: When Discourses Meet, 13 Michigan Journal of International Law 517 (1992).

Engle, K., National Sovereignty Revisited: Perspectives on the Emerging Norm of Democracy in International Law. 86 Proceedings of the American Society of International Law 249 (1992).

Engle, K., Female Subjects of Public International Law: Human Rights and the Exotic Other Female, 26 Ncw England Law Rcview 1509 (1992).

Engle, K., Views From the Margins: A Response to David Kennedy, 1 Utah Law Review 105 (1994).

Gross, A.M., Reinforcing the New Democrats: The European Convention on Human Rights and the Former Communist Countries - A Study of the Case Law, 7 European Iournal of International Law 89 (1996).

Hartnell, H.E., Rousing the Sleeping Dog: The Validity Exception to the Convention on Contracts for the International Sale of Goods, 18 Yale Joumal of International Law 1 (1993).

Hartnell, H.E., The NEW New International Economic Order: Private International Law, 87 Proceedings of the American Society of International Law 462 (1993).

Heiskanen, V.A., Living on International Law. Finnish Yearbook of International Law, 3 Finnish Yearbook of International Law 414 (1992).

Kennedy, D., Theses 1bout Intemational Law Discourse, 23 German Yearbook of International Law 353 (1980).

Kennedy, D., The Turn to Interpretation, 58 Southern California Law Review 251 (1985).

Kennedy, D., Spring Break, 63 Texas Law Review 1377 (1985).

Kennedy. D.. International Legal Education. 26 Harvard International I aw Journal 361 (1985).

Kennedy, D., Primitive Legal Scholarship, 27 Harvard International Law Journal 1 (1986).

Kennedy, D., The Sources of International Law, 2 American University Journal of International Law and Policy 1 (1987). 
Kennedy, D., The Move to Institutions, 8 Cardozo Law Review 841 (1987).

Kennedy, D., A New Stream of International Law Scholarship, 7 Wisconsin International Law Journal 1 (1988).

Kennedy, D., Images of Religion in International Legal Theory, in M. Janis (Ed.), The Influcnce of Religion in the Devclopment of International Law 137 (1991).

Kennedy, D., Autumn Weekends: An Essay on Law and Everyday Life, in A. Sarat \& T.R. Kearns (Eds.), Law and Everyday Life 191 (1993).

Kennedy, D., A New World Order: Yesterday, Today, and Tomorrow, 4 Transnational Law \& Contemporary Problems 329 (1994).

Kennedy, D. \& Tennant, C., New Approaches to International Iaw. A Rihlingraphy, 35 Harvard International Law Journal 417 (1994).

Kennedy, D., The International Style in Postwar Law and Policy, 1 Utah Law Review 7 (1994), also reproduced in 10 American University Juurnal of International Law and Policy 671 (1995).

Kennedy, D., Receiving the International, 10 Connecticut Journal of International Law 1 (1994).

Kennedy, D., International Law and the Nineteenth Century: History of an Illusion, 65 Nordic Journal of International Law 385 (1996).

Kingsbury, B., Claims by Non-State Groups in International Law, 25 Cornell International Law Joumal 48 (1992).

Kingsbury, B., Soveretgnty and Non-State, 88 Proceedings of the American Society of International Law 1 (1994).

Kingsbury, B., Environment and Trade: The GATT/WTO Regime in the International Legal System, in Boyle, A. (Ed.), Economic Growth and Environmental Regulation 189 (1994).

Kingsbury, B., The Tuna-Dolphin Controversy, the World Trade Organization, and the Liberal Project to Reconceptualize International Law, 5 Yearbook of International Environmental Law 1 (1995).

Knop, K., Re/Statements: Feminism and State Sovereignty in International Law, 3 Transnational Law \& Contemporary Problems 293 (1993).

Knop, K., The "Righting" of Recognition: Recognition of States in Eastern Furope and the Soviet Union, in Canadian Council on International Law Proceedings 36 (1992).

Korhonen, O., New International Law: Silence, Defence, or Deliverance, 7 European Journal of International Law 1 (1996).

Korhonen, O., Current Trends in European International Law Publications, 9 European Journal of International Law 552 (1998).

Korhonen, O., Liberalism and International Law in the Nineties, 65 Nordic Journal of International Law 481 (1996).

Korhonen, O., The Place of Ethics in International Law, 21 Retfærd 3 (1998).

Koskenniemi, M., General Principles: Reflexions on Constructivist Thinking in International Law, 18 Oikeustiede/Jurisprudentia 121 (1985).

Koskenniemi, M., Sovereignty: Prolegomena to a Study of International Law as a Discourse, Kansainoikeus/ Jus Gentium 71 (1987).

Koskenniemi, M., The Hobbesian Structure of International Legal Discourse, in T. Airaksinen \& M.A. Bertman (Eds.), T. Hobbes: War Among Nations 168 (1989).

Koskenniemi, M., The Normative Force of Habit: International Custom and Social Theory, 1 Finnish Yearbook of International Law 77 (1990).

Koskenniemi, M., The Politics of International Law, 1 European Journal of International Law 4 (1990). 
Koskenniemi, M., Theory: Implications for the Practitioner, in C. Warbrick et al., Theory and International Law: An Introduction 1 (1991).

Koskenniemi, M., The Future of Statehood, 32 Harvard International Law Journal 397 410 (1992).

Koskenniemi, M., National Self-Determination Today: Problems of Legal Theory and Practice, 43 International and Comparative Law Quarterly 241 (1994).

Koskenniemi, M., The Wonderful Artificiality of States, 88 Proceedings of the American Society of International Law 22 (1994).

Koskenniemi, M., International Law in the Post-Realist Era, 16 Australian Yearbook of International Law 1 (1995).

Koskenniemi, M., The Police in the Temple. Order, Justice and the UN; A Dialectical View, 5 European Journal of International Law 325 (1995).

Koskennemı, M. \& Lehto, M., The Privilege of Universality: Economic Ideology, Seabed Resources and International Law, 65 Nordic Journal of International Law 533 (1996).

Koskenniemi, M. (Guest Editor), Special Issue: New Approaches to International Law, 65 Nordic Journal of International Law (1996).

Koskenniemi, M., Faith, Identity and the Killing of the Innocent: Intemational Lawyers and Nuclear Weapons, 10 Leiden Journal of International Law 137 (1997).

Koskenniemi, M., Lauterpacht: The Victorian Tradition in International Law, 8 European Journal of International Law 215-263 (1997).

Koskenniemi, M., Hierarchy in International Law: A Sketch, 8 European Journal of International Law 566-582 (1997).

Lam, M., Making Room for Peoples at the United Nations: Thoughts Provoked by Indigenous Claims to Self-determination, 25 Cornell International Law Journal 603 (1992).

Lam, M., Feeling Foreign in Feminism, 19 Journal of Women in Culture and Society 865 (1994).

Leary, V.A., Postliberal Strands in Western Human Rights Theory: PersonalistCommunitarian Perspectives, in A.A. An-Naim (Ed.), Human Rights in CrossCultural Perspectives: A Quest for Consensus 105 (1992)

Mahmud, T., Jurisprudence of Successful Treason: Coup d'Etat of Common Law, 27 Cornell International Law Journal 49 (1994).

Mahmud, T., International Law and the "Race-ed" Colonial Encounter, 91 Procedings of the American Society of International Law 414 (1997).

Marks, S., Civil Liberties at the Margin: The UK Derogation and the European Court of Human Rights, 15 Oxford Journal of Legal Studies 69 (1995).

Marks, S., The European Convention on Human Rights and Its "Democratic Society", 66 Rritish Yearhook of International I aw 209 (1995)

Marks, S., The End of History? Reflections on Some International Legal Theses, 8 European Journal of International Law 449 (1997).

Morgàn, D.E., Internalization of Customary International Law: An Historical Perspective, 12 Yale Journal of International Law 63 (1987).

Morgan, D.E., Aliens and Process Rights: The Open and Shut Case of Legal Sovereignty, 7 Wisconsin International Law Journal 107 (1988).

Morgan, E.M., The Imagery and Meaning of Self-Determination, 20 New York University Inurnal of International I aw and Policy 355 (1987-1988).

Morgan, E.M., Retributory Theater, 3 American University Journal of International Law and Policy 1 (1988). 
Morgan, E.M., The Hermaphroditic Paradigm of International Law: A Comment on Alvarez-Machain, Proceedings of the Canadian Council of International Law 78 (1992).

Mutua, M.W., The Banjul Charter and the African Cultural Fingerprint: An Evaluation of the Language of Duties, 35 Virginia Journal of International Law 339 (1995).

Mutua, M.W., Why Redraw the Map of Africa: A Moral and Legal Inquiry, 16 Michigan Journal of International Law 1113 (1995).

Mutua, M.W., The Interaction Between Human Rights, Democracy, Governance and Displacement of Populations, 7 International Journal of Refugee Law 37 (1995).

Mutua, M W. The Idenlngy of Human Rights, 36 Virginia Journal of International Law 589 (1996).

Mutua, M.W., Never Again: Questioning the Yugoslav and Rwanda Tribunals, 11 Temple International and Comparative Law Juunal 167 (1997).

Otto, D., Rethinking the 'Universality' of Human Rights Law, 29 Columbia Human Rights Law Review 1-46 (1997).

Paul, J.R., The Isolation of Private International Law, 7 Wisconsin International Law Journal 149 (1988).

Paul, J.R., Comity in International Law, 32 Harvard International Law Journal 1 (1991).

Rajagopal, B. \& Carroll, A.J., The Case for the Independent Statehood of Somaliland, 8 American University Journal of International Law and Policy 653 (1992-1993).

Rajagopal, B., Crossing the Rubicon: Synthesizing the Soft International Law of the IMF and Human Rights, 11 Boston University Journal of International Law 81 (1993).

Riles, A., Representing In-Between: Law. Anthropology. and the Rhetoric of Interdisciplinarity, University of Illinois Law Review 597 (1994).

Riles, A., The View From the International Plane: Perspective and Scale in the Architecture of Colonial International Law, 6 Law and Critique 39 (1995).

Romany, C., Women as Aliens: A Feminist Critique of the Public/Private Distinction in International Human Rights Law, 6 Harvard Human Rights Journal 87 (1995).

Stark, B., Postmodern Rhetoric, Economic Rights and an International Text: "A Miracle for Breakfast", 33 Virginia Journal of International Law 433 (1993).

Stark, B., Intemational Human Rights Law, Feminist Jurispmedence and Nietzrche's Eternal Return: Turning the Wheel, 19 Harvard Women's Law Journal 169 (1996).

Tallgren, I., Completing the 'International Criminal Order', 67 Nordic Journal of International Law 107-137 (1998).

Tennant, C. \& Turpel, M.E., A Case Study of Indigenous Peoples: Genocide, Ethnocide and Self-Determination. 59 Nordic Journal of International Law 287 (1990).

Tennant, C. \& Kennedy, D., New Approaches to International Law: A Bibliography, 35 Harvard International Law Journal 417 (1994).

Temant, C., Indigenous Peoples, International Institutions, and the International Legal Literature From 1945-1993, 16 Human Rights Quarterly 1 (1994).

Turpel, M.E \& Tennant, C., A Case Study of Indigenous Peoples: Genocide, Ethnocide and Self-Determination, 59 Nordic Journal of International Law 287 (1990).

Wrange, P., Law, Force and Contingency. Notes on a Bold Monograph on Article 2(4) and the Problems of Finding a Proper Basis far Internatianal Legal Reasoning, 61 Nordic Journal of International Law 83 (1992).

Wrange, P., The Concept of Sovereignty: Alive and Kickin', 6 Juridisk Tidskrift vid Stockholms Universitet 350 (1994-1995).

Wright, S., Charlesworth, H. \& Chinkin, C., Feminist Approaches to International Law, 85 American Journal of International Law 613 (1991). 
Wright, S. \& Chinkin, C., The Hunger Trap: Women, Food, and Self-Determination, 14 Michigan Journal of International Law 262 (1993). 